\title{
SPECIFIČNOSTI JAVNE NABAVE KOD SEKTORSKIH ENERGETSKIH NARUČITELJA
}

\author{
UDK: 35 (4) \\ Pregledni rad \\ Primljeno: 20. 12. 2016.
}

\begin{abstract}
U radu se analiziraju diferencijalno uređenje i primjena postupaka javne nabave na nabavne postupke sektorskih naručitelja u svim vrstama energetskih djelatnosti. Analiza će se sastojati od dva dijela, europskog i hrvatskog. U europskom dijelu javna nabava kod naručitelja koji obavljaju energetske djelatnosti neodvojiva je od šireg pojma „komunalnih usluga” (utilities), te će se stoga analizirati razvoj primjene pravila javne nabave na nabavu naručitelja koji pružaju energetske usluge u kontekstu povijesnih i sadašnjih pravnih shvaćanja o komunalnim uslugama. Također, analizirat će se i promjena javnonabavnih pravila primjenjivih na energetske naručitelje. U drugom dijelu rada, analizirat će se pravni okvir za energetske naručitelje u Republici Hrvatskoj.
\end{abstract}

Ključne riječi: javna nabava, energetske djelatnosti, Europska unija, Republika Hrvatska

\section{UVOD}

Javna nabava zauzima iznimno važno mjesto u pravnom poretku Europske unije (u nastavku: EU), ali i Republike Hrvatske. Njezin je utjecaj na trošenje javnih (proračunskih) sredstava izniman, kao što je izniman i utjecaj javne nabave na gospodarsku djelatnost općenito. „Klasična” javna nabava, ako je takvom možemo nazvati, ima jednostavne odrednice. Javni naručitelji (koje čine tijela državne uprave, jedinice lokalne i područne samouprave...), zbog racionalnog trošenja proračunskih sredstava i unapređenja tržišnog natjecanja, primjenjuju pravila javne nabave na svu nabavu iznad propisanih pragova. Dakle, navedeni javni naručitelji u potpunosti (ili bar većim dijelom) financiraju se iz državnog proračuna. Situacija je puno nejasnija kada se određena pravna osoba većinski financira pružanjem svojih usluga na tržištu, a ta usluga je iznimno važna za funkcioniranje države, te tržište nije u potpunosti razvijeno i sama država ima određeni vlasnički udio u samoj pravnoj osobi. Pitanje koje se javlja jest: trebaju li i takve pravne osobe primjenjivati pravila javne nabave kada pribavljaju dobra, radove ili usluge?

Kroz pravo EU, za usluge koje pružaju takve pravne osobe uvriježio se pojam komunalne usluge. Komunalne usluge, iako fluidan i promjenjiv pojam, kroz povijest 
je podrazumijevao pružanje usluga vodoopskrbe, telekomunikacijskih usluga, poštanskih usluga, prometnih usluga i usluga opskrbe energijom. ${ }^{1}$ Specifičnosti komunalnih usluga kao posljedicu su povijesno imale izostanak primjene prava javne nabave na njihovu nabavu robe, dobara i usluga unutar EU. Tek početkom 1990-ih situacija se počinje mijenjati.

Energetski sektor, unutar komunalnih usluga, ima posebnu važnost. Različiti izvori energije, njihov utjecaj na gospodarsku aktivnost, cijena i ovisnost zemalja članica EU o uvozu energije iz trećih zemalja učinili su energetski sektor iznimno važnim, a takva gospodarska važnost i tržišna prisutnost često pružatelje energetskih usluga čine pravnim osobama na razmeđu javnoga i privatnoga prava. Također, inzistiranje EU na otvaranju energetskog sektora tržišnom natjecanju, pa posljedično i polagano otvaranje i liberaliziranje hrvatskog energetskog tržišta, stavili su energetski sektor u fokus pravnoga razmišljanja i u Republici Hrvatskoj. Sve te specifičnosti dovode i do nužno posebnog javnonabavnog režima kod naručitelja iz energetskog sektora.

Rad ćemo započeti prikazom razvoja javnonabavnog pravnog okvira EU za naručitelje iz energetskog sektora. Koncentrirat ćemo se na vrste energetskih djelatnosti koje su obuhvaćene relevantnim direktivama EU, kao i na postupovne novine koje donose regulatorni okviri. Poseban naglasak bit će na novom regulatornom okviru iz 2014. U drugom dijelu rada prikazat ćemo razvoj javnonabavnih pravila za energetski sektor u Republici Hrvatskoj, s posebnim osvrtom na utjecaj regulatornog okvira iz 2014. na hrvatski pravni sustav.

\section{KOMUNALNE USLUGE - POČETAK DIFERENCIJALNOG JAVNONABAVNOG TRETMANA}

Ideja o potrebi stvaranja zajedničkih javnonabavnih pravila za sve države članice pojavila se relativno rano u razvoju EU. Glavni poticaj bila je spoznaja kako neće postojati zajedničko tržište ukoliko i veliko javnonabavno tržište ne bude otvoreno za ponuditelje iz svih država članica. Tako je prva javnonabavna Direktiva usvojena već 1971. ${ }^{2}$ Ipak, komunalne usluge, pa tako i energetske, bile su isključene iz tog i iz svih sljedećih javnonabavnih regulatornih okvira EU sve do 1990. Iako je prepoznata potreba za primjenu pravila javne nabave i na komunalne usluge, razlozi za ovakav pristup bili su višestruki.

Zbog veličine nabave koju provode pružatelji komunalnih usluga, takva nabava smatrala se važnim instrumentom domaće industrijske politike država članica, te

\footnotetext{
Komunalne usluge mogu se smatrati mrežnim industrijama, vidi Turudić, M., „Utjecaj Meroni presude na zajedničko tržište za mrežne industrije“, Zbornik radova Zagrebačko-skopskog kolokvija, Zagreb: Pravni fakultet Sveučilišta u Zagrebu, 2015., str. 323-346.

2 Direktiva 71/305/EEC o koordinaciji postupaka za dodjelu ugovora o javnim radovima, Službeni list Europskih zajednica 185/5.
} 
su države članice bile izrazito protiv podvrgavanja takve nabave transparentnom i kompetitivnom režimu javne nabave EU, s obzirom na to da su se oslanjale na preferencijalne i zatvorene postupke nabave kako bi održavale svoje strateške industrije, kakvim su smatrale i pružanje komunalnih usluga. ${ }^{3}$ Država i pružatelji komunalnih usluga tada su imali i posebne međuodnose. Države su mogle imati izravan utjecaj na nabavu pružatelja komunalnih usluga, kroz sudjelovanje u njihovu kapitalu i kroz predstavnike u njihovim upravnim i nadzornim tijelima. ${ }^{4}$

Također, pružanje komunalnih usluga zahtijeva velike investicije i tehnički je složeno pa je određena posebna prilagodba javnonabavnih postupaka bila potrebna kako bi se poštovale specifičnosti javne nabave u komunalnim uslugama. ${ }^{5}$ Upravo zbog te tehničke složenosti, iznosi nabave pružatelja komunalnih usluga (poglavito u energetskom sektoru) bili su vrlo visoki, prosječno značajno viši od javne nabave u javnom sektoru. Stoga je bilo nužno posebnim pravnim propisima prilagoditi pragove javne nabave posebno za pružatelje komunalnih usluga, kako se direktnom primjenom pragova iz javnog sektora ne bi ugrozilo de minimis načelo kao jedno od ključnih načela postupaka javne nabave. ${ }^{6}$

Posebna prilagodba javnonabavnih postupaka bila je nužna i zbog činjenice što su pružatelji komunalnih usluga navikli na djelovanje u zatvorenim tržištima, na temelju posebnih ili ekskluzivnih prava koja su im dale države članice. Upravo zbog toga, unutar EU postojala je svijest da će biti nužno zamisliti poseban pravni režim za pružatelje komunalnih usluga, kako bi ih se u djelovanju približilo javnim tijelima sukladno već tada postojećim javnonabavnim direktivama, ali i osnovnim načelima prava EU.?

Dodatan razlog za isključivanje pružatelja komunalnih usluga iz javnonabavnih regulatornih okvira EU i naglašavanje potrebe za budućim diferencijalnim javnonabavnim pravnim režimom bila je činjenica da pružatelji komunalnih usluga u različitim državama članicama imaju različit pravni status, od pravnih osoba u potpunom državnom vlasništvu do privatnih pravnih osoba. ${ }^{8}$

Bovis, C., The Law of EU Public Procurement, Oxford, 2015., str. 35.

4 Bovis, C., op cit. (bilj. 3.), str. 35.

5 Torricelli, S., ,The utility sectors: a field of tension between EU and Member states“, u: EU Public Contract Law: Public Procurement and Beyond, Bruylant, Bruxelles, 2014., str. 225.

6 Bovis, C., op cit. (bilj. 3.), str. 36.

7 Bovis, C., op cit. (bilj. 3.), str. 35.

8 Bovis, C., op cit. (bilj. 3.), str. 35. 


\section{DIREKTIVA 90/531/EEC}

Traženje prihvatljivog modela podvođenja komunalnih usluga pod javnonabavni pravni poredak trajalo je punih 20 godina. Tek 1990. usvojena je Direktiva 90/531/ EEC, ${ }^{9}$ kojom se pružatelji energetskih i ostalih komunalnih usluga podvode pod (fleksibilniji) javnonabavni režim. Direktiva 90/531/EEC obvezuje širok krug pružatelja energetskih usluga. Tako se navodi kako se primjenjuje na javna tijela ili javna poduzeća, ili privatna poduzeća koja na temelju posebnih ili ekskluzivnih prava ${ }^{10}$ danih od strane nadležnog tijela ili države članice pružaju usluge ili upravljaju fiksnim mrežama putem kojih se javnosti pružaju usluge električne energije ili plina i grijanja, ili opskrba električnom energijom, plinom ili grijanjem kroz te mreže. ${ }^{11}$

Kako je ova Direktiva predstavljala kompromis između želja EU i država članica koje su se protivile provođenju svojih strateških gospodarskih sektora pod transparentna javnonabavna pravila zajedničkog tržišta, ne čudi da je Direktiva sadržavala i značajne iznimke od primjene Direktive u energetskom sektoru. Tako, ako tijelo koje nije javno tijelo, a bavi se pružanjem usluga električne energije, plina ili grijanja javnosti, neće se smatrati relevantnom aktivnosti za primjenu ove Direktive: u slučaju električne energije - ako se energija proizvodi zato što je njezina potrošnja nužna za obavljanje aktivnosti koje nisu navedene u članku 2. stavku 2., te ako opskrba javne mreže ovisi samo o vlastitoj potrošnji tijela i nije prešla $30 \%$ ukupne proizvodnje energije tog tijela, uzevši u obzir trogodišnji prosjek. ${ }^{12}$ Ako je riječ o uslugama plina ili grijanja, iznimka je propisana ako je proizvodnja plina ili grijanja neizbježna posljedica provođenja aktivnosti koja nije navedena $u$ članku 2. stavku 2., te ako je opskrba javne mreže usmjerena samo ekonomskom iskorištavanju takve proizvodnje i ne prelazi $20 \%$ prometa tog tijela sukladno trogodišnjem prosjeku. ${ }^{13}$ Također, državama članicama ostavljena je mogućnost da od Europske komisije zatraže da se iskorištavanje određenih zemljopisnih područja za svrhu istraživanja ili vađenja nafte, plina, ugljena ili drugih krutih goriva isključi iz opsega primjene Direktive. ${ }^{14}$

Jedan od glavnih prigovora država članica - da su nabave koje provode pružatelji enegetskih, ali i ostalih komunalnih usluga značajno veće vrijednosti od standardnih javnih nabava - adresiran je člankom 12., kojim su propisani pragovi javne nabave za energetske i ostale komunalne djelatnosti. Prag od 400.000 ECU-a propisan je za nabavu dobara što je provode pružatelji usluga vode, električne energije, plina ili grijanja, za nabavu dobara što je provode tijela koja istražuju ili vade naftu, plin,

9 Direktiva o postupcima nabave za pravne osobe koje djeluju u sektorima vodoopskrbe, energije, prijevoza i telekomunikacija, Službeni list Europskih zajednica 297/1.

10 „Posebna ili ekskluzivna prava su prava koja proizlaze iz dozvola što ih dodjeljuje nadležno tijelo ili država članica zakonom, podzakonskim aktom ili upravnim aktom, čiji je rezultat rezerviranje obavljanja djelatnosti iz članka 2. stavka 2. za određeno tijelo", članak 2 stavak 3. Direktive 90/531/EEC.

11 Članak 2. stavak 1. i 2. a) Direktive 90/531/EEC.

12 Članak 2. stavak 5. točka a) Direktive 90/351/EEC.

13 Članak 2. stavak 5. točka b) Direktive 90/351/EEC.

14 Vidi članak 3. Direktive 90/352/EEC. 
ugljen ili druga kruta goriva, kao i pružatelji prometnih usluga. ${ }^{15}$ Prag od 600.000 ECU-a propisan je za nabavu koju provode tijela koja pružaju telekomunikacijske usluge, a 5.000.000 ECU-a za nabavu radova za sve pružatelje komunalnih usluga. ${ }^{16}$ Navedeni pragovi značajno su viši od onih koji su u trenutku donošenje Direktive 90/531/EEC vrijedili za nabavu u javnom sektoru; ti pragovi kretali su se od 130.000 do 200.000 ECU-a. ${ }^{17}$

Direktiva 90/531/EEC izmijenjena je 1993. Direktivom 93/38/EEC, ${ }^{18}$ koja nije suštinski mijenjala odredbe o primjeni Direktive 90/531/EEC, kao ni pragove. Ni naknadne izmjene Direktive 93/38/EEC iz $1994 .{ }^{19}$ i $1998 .{ }^{20}$ ne dotiču opisane odredbe.

\section{DIREKTIVA 2004/17/EC}

Direktiva 2004/17/EC 21 usvojena je nakon 11 godina primjene prošlog javnonabavnog regulatornog režima za komunalne usluge. Značajna novina nove Direktive jest isključenje pružatelja telekomunikacijskih usluga iz obveznika primjene. Razlog za takvo isključenje jest činjenica da je u trenutku usvajanja Direktive ustanovljeno kako je u telekomunikacijskom tržištu postignuta dovoljna kvaliteta tržišnog natjecanja koja opravdava isključivanje provođenja javne nabave za pružatelje telekomunikacijskih usluga. ${ }^{22}$ Naveden primjer pokazuje kako nije nemoguce zamisliti neku buduću Direktivu koja će predvidjeti isključenje pružatelja energetskih usluga iz primjene pravila javne nabave ukoliko se uspije uspostaviti dovoljno učinkovito energetsko slobodno tržište. Također, u opseg primjene Direktive uključeni su pružatelji poštanskih usluga. Pružatelji poštanskih usluga

15 Članak 12. stavak 1. točka a) Direktive 90/352/EEC.

16 Članak 12. stavak 1. točka b) i c) Direktive 90/352/EEC.

17 Članak 5. Direktive 88/295/EEC.

18 Direktiva 93/38/EEC o koordinaciji postupaka nabave tijela koja djeluju u sektorima vodoopskrbe, energije, prijevoza i telekomunikacija, Službeni list Europskih zajednica 199/84.

19 Direktiva 94/22/EEC o uvjetima za dodjelu i korištenje dozvola za istraživanje i proizvodnju ugljikovodika, Službeni list Europske unije L 164.

20 Direktiva 98/4/EC kojom se mijenja Direktiva 93/38/EEC o koordinaciji postupaka nabave tijela koja djeluju u sektorima vodoopskrbe, energije, prijevoza i telekomunikacija, Službeni list Europske unije L $101 / 1$.

${ }^{21}$ Direktiva od 31. ožujka 2004. o usklađivanju postupaka nabave subjekata koji djeluju u sektoru vodnog gospodarstva, energetskom i prometnom sektoru te sektoru poštanskih usluga, Službeni list Europske unije 134/1.

22 „Područje primjene Direktive 98/38/EEZ trenutačno obuhvaća određene ugovore koje sklapaju naručitelji koji djeluju u telekomunikacijskom sektoru. S ciljem otvaranja ovog sektora donesen je zakonodavni okvir, kao što se navodi u Četvrtom izvještaju o provedbi telekomunikacijskih propisa od 25. studenoga 1998. Jedna od njegovih posljedica bilo je uvođenje stvarnog tržišnog natjecanja de jure $\mathrm{i}$ de facto u ovom sektoru. U svrhu informiranja i u svjetlu ove situacije, Komisija je objavila popis telekomunikacijskih usluga koje se već mogu isključiti iz područja primjene te Direktive na temelju njezina članka 8. Daljnji napredak bio je potvrđen u Sedmom izvještaju o provedbi telekomunikacijskih propisa od 26. studenoga 2001. Stoga više nije potrebno regulirati nabave subjekata koji djeluju u ovom sektoru.", paragraf 5. Direktive 2004/17/EC. 
Dr. sc. Marko Turudić i dr. sc. Bosiljka Britvić Vetma: Specifičnosti javne nabave kod sektorskih... Zbornik radova Pravnog fakulteta u Splitu, god. 54, 1/2017., str. 159.-178.

do 2004. nisu bili obveznici primjene pravila o javnoj nabavi, te je Direktivom ostavljen rok do kraja 2008. kako bi se države članice stigle pripremiti na ovu izmjenu. ${ }^{23}$

U prikazu najvažnijih odredbi Direktive 2004/17/EC koncentrirat ćemo se na vrste tijela koja su je dužna primjenjivati, na energetske djelatnosti, na iznimke od primjene Direktive i na pragove.

Direktiva se primjenjuje na tri vrste tijela: na javne naručitelje, javna poduzeća i na pravne osobe koje nisu javni naručitelji ni javna poduzeća, ako djeluju na temelju posebnih ili isključivih prava što im ih je dodijelilo nadležno tijelo države članice. Definicija javnih naručitelja identična je definiciji koja postoji u Direktivi 2004/18/ EC, koja regulira opću javnu nabavu u javnom sektoru. Javno poduzeće definirano je kao poduzeće u kojem javni naručitelji mogu imati, izravno ili neizravno, prevladavajući utjecaj na temelju njihova vlasništva u njemu, financijskog udjela u njemu, ili na temelju pravila prema kojima se ravna. ${ }^{24}$ Dodatna novina Direktive 2004/17/EC jest detaljnije definiranje posebnih ili isključivih prava, koja se definiraju kao prava što ih dodjeljuje nadležno tijelo države članice na temelju bilo koje odredbe zakona, drugog propisa ili upravnog akta čiji je učinak ograničavanje izvršavanja djelatnosti određenih u člancima od 3. do 7. (plin, toplinska i električna energija, voda, prijevozne usluge, poštanske usluge, traženje ili vađenje nafte, plina, ugljena ili drugih krutih goriva, kao i luke i zračne luke) na jednog subjekta ili više njih, i koji ima znatan utjecaj na mogućnost drugih subjekata da obavljaju takvu djelatnost. ${ }^{25}$

Od svih navedenih djelatnosti na koje se primjenjuje Direktiva, prikazat ćemo djelatnosti koje se odnose na energiju. Tako se Direktiva primjenjuje na pružanje fiksnih mreža ili upravljanje fiksnim mrežama s namjerom pružanja usluge javnosti $\mathrm{u}$ vezi s proizvodnjom, prijenosom ili distribucijom plina, toplinske i električne energije ili pak na isporuku plina, toplinske i električne energije takvim mrežama. ${ }^{26}$ Također, propisane su i iznimke od navedenih pravila. ${ }^{27}$ Direktiva se primjenjuje

23 Allain, Y., „,The New European Directives on Public Procurement: Change or Continuity?“, Public Contract Law Journal, Vol. 35 No. 3 2006., str. 533.

24 Članak 2. stavak 1. točka b) Direktive 2004/17/EC.

25 Članak 2. stavak 3. Direktive 2004/17/EC, vidi i Bovis, C., The New Public Procurement Regime; A Different Perspective on the Integration of Public Markets of the European Union, European Public Law, Volume 12, Issue 1, 2006., str. 98.

26 Članak 3. stavak 1. Direktive 2004/17/EC.

27 „Isporuka plina ili toplinske energije mrežama koje pružaju uslugu javnosti od strane naručitelja koji nije javni naručitelj ne smatra se relevantnom djelatnošću u smislu stavka 1. ako je:

(a) proizvodnja plina ili toplinske energije od strane tog subjekta neizbježna posljedica obavljanja djelatnosti koja nije djelatnost iz stavka 1. ili 3. ovog članka, ili iz članaka od 4. do 7.; i

(b) jedini cilj isporuke javnoj mreži ekonomsko iskorištavanje takve proizvodnje i ne iznosi više od $20 \%$ prometa tog subjekta uzimajući u obzir prosjek prethodne tri godine, uključujući tekuću godinu.

Isporuka električne energije mrežama koje pružaju uslugu javnosti putem od strane naručitelja koji nije javni naručitelj ne smatra se relevantnom djelatnošću u smislu stavka 3. ako: 
i na djelatnosti koje se odnose na iskorištavanje zemljopisnog područja u svrhu traženja ili vađenja nafte, plina, ugljena ili drugih krutih goriva. ${ }^{28}$

Uz već spomenute iznimke od primjene Direktive koje se odnose na podvrste energetskih djelatnosti, Direktiva se također nije primjenjivala na ugovore koji se sklapaju u svrhu prodaje ili iznajmljivanja trećim osobama, ${ }^{29}$ na ugovore koji se sklapaju u svrhe koje ne uključuju obavljanje obuhvaćene djelatnosti ili u svrhu obavljanja takve djelatnosti u trećoj zemlji ${ }^{30}$ na ugovore koji su tajni ili zahtijevaju posebne mjere sigurnosti, ${ }^{31}$ ugovore koji se sklapaju u skladu s međunarodnim pravilima $^{32}$ i na ugovore koji se sklapaju s povezanim društvom, zajedničkim pothvatom ili naručiteljem koji je sastavni dio zajedničkog pothvata. ${ }^{33}$

Pragovi su u Direktivi 2004/17/EC pretrpjeli značajne izmjene. Direktiva 90/531/EC razlikovala je pragove s obzirom na komunalnu djelatnost koju obveznik obavlja, dok nova Direktiva postavlja pragove neovisne o komunalnoj djelatnosti. Tako se Direktiva primjenjuje na ugovore čija procijenjena vrijednost bez poreza na dodanu vrijednost nije manja od sljedećih pragova: 499.000 eura u slučaju ugovora o nabavi robe i ugovora o uslugama, i 6.242 .000 eura u slučaju ugovora o radovima. ${ }^{34}$

\section{DIREKTIVA 2014/25/EU}

Novi javnonabavni regulatorni okvir EU usvojen je 2014. Sastoji se od tri direktive; opće, Direktive 2014/24/EU, ${ }^{35}$ Direktive 2014/23/EU ${ }^{36}$ koja prvi put samostalno uređuje koncesije, te Direktive 2014/25/EU, ${ }^{37}$ kojom se uređuje javna nabava za pružatelje komunalnih usluga, pa tako i pružatelja usluga energije. Novi regulatorni okvir rezultat je dugogodišnjeg istraživanja i promišljanja o učincima

(a) se proizvodnja električne energije od strane tog subjekta obavlja zbog toga što je njezina potrošnja potrebna za obavljanje djelatnosti koja nije djelatnost iz stavka 1. ili 3. ovog članka, ili iz članaka od 4. do $7 . ;$ i

(b) isporuka javnoj mreži ovisi samo o vlastitoj potrošnji subjekta i ne iznosi više od $30 \%$ ukupne proizvodnje energije subjekta uzimajući u obzir prosjek prethodne tri godine, uključujući tekuću godinu.", Članak 3. stavci 2. i 4. Direktive 2004/17/EC.

28 Članak 7. Direktive 2004/17/EC.

29 Članak 19. Direktive 2004/17/EC.

30 Članak 20. Direktive 2004/17/EC.

31 Članak 21. Direktive 2004/17/EC.

32 Članak 22. Direktive 2004/17/EC.

33 Članak 23. Direktive 2004/17/EC.

34 Članak 16. Direktive 2004/17/EC.

35 Direktiva 2014/24/EU Europskog parlamenta i Vijeća od 26. veljače 2014. o javnoj nabavi i o stavljanju izvan snage Direktive 2004/18/EZ.

36 Direktiva 2014/23/EU Europskog parlamenta i Vijeća od 26. veljače 2014. o dodjeli ugovora o koncesiji.

37 Direktiva 2014/25/EU Europskog parlamenta i Vijeća od 26. veljače 2014. o nabavi subjekata koji djeluju u sektoru vodnog gospodarstva, energetskom i prometnom sektoru te sektoru poštanskih usluga i stavljanju izvan snage Direktive 2004/17/EZ. 
regulatornog okvira iz 2004. i razvoja zajedničkog javnonabavnog tržišta. Tako je ustanovljeno da se pravila o javnoj nabavi donesena na temelju Direktive 2004/17/ EZ te Direktive 2004/18/EZ trebaju revidirati i unaprijediti kako bi se povećala djelotvornost javne potrošnje, a pogotovo kako bi se olakšalo sudjelovanje malih i srednjih poduzeća u javnoj nabavi te kako bi se dobavljačima omogućilo da bolje iskoriste javnu nabavu pri postizanju zajedničkih društvenih ciljeva. ${ }^{38}$ Ustanovljena je i potreba za pojašnjenjem temeljnih pojmova i koncepata kako bi se osigurala bolja pravna sigurnost i uzeli u obzir određeni aspekti povezane, dobro utvrđene sudske prakse Suda Europske unije. ${ }^{39}$

Unutar novog regulatornog okvira, Direktiva 2014/24/EU i Direktiva 2014/25/ EU sadrže mnoge sličnosti u provođenju postupaka javne nabave. Ipak, postoje i određena značajna odstupanja koja su nužna da bi se pružateljima komunalnih usluga osigurao fleksibilniji pristup provođenju postupaka javne nabave. Stoga ćemo se u ovom poglavlju osobito osvrnuti na pružatelje energetskih usluga koji su obveznici primjene Direktive 2014/25/EU, na promjene u pragovima, kao i (po našem mišljenju) najvažnije novine kojima predmetna Direktiva mijenja sustav javne nabave za pružatelje energetskih, kao i ostalih komunalnih usluga.

Kao u prethodnoj direktivi, i u Direktivi 2014/25/EU kao obveznici primjene Direktive definiraju se javni naručitelji i naručitelji. ${ }^{40}$ Novost je u definiciji posebnih ili isključivih prava, te se naglašava kako se prava dodijeljena putem postupka koji se temelji na objektivnim kriterijima, posebno na zakonodavstvu Unije, te za koja je osigurana odgovarajuća objava u javnosti, ne smatraju posebnim ili isključivim pravima za potrebe ove Direktive. ${ }^{41}$

Što se tiče pružatelja usluga energije, ova Direktiva primjenjuje se na pružanje fiksnih mreža ili upravljanje fiksnim mrežama s namjerom pružanja usluge javnosti u vezi s proizvodnjom, prijenosom ili distribucijom plina ili toplinske energije $i$ isporuku plina ili toplinske energije takvim mrežama ${ }^{42}$ Također, primjenjuje se i na pružanje fiksnih mreža ili upravljanje fiksnim mrežama s namjerom pružanja usluge javnosti u vezi s proizvodnjom, prijenosom ili distribucijom električne energije i isporuku električne energije takvim mrežama. ${ }^{43}$

38 Paragraf 4. Direktive 2014/25/EU.

39 Paragraf 4. Direktive 2014/25/EU.

40 Članci 3. i 4. Direktive 2014/25/EU.

41 Paragraf 20. i članak 4. stavak 3. Direktive 2014/25/EU.

42 „Isporuka plina ili toplinske energije od strane naručitelja koji nije javni naručitelj fiksnim mrežama koje pružaju uslugu javnosti ne smatra se relevantnom djelatnošću u smislu stavka 1 . ako su ispunjeni svi sljedeći uvjeti:

(a) proizvodnja plina ili toplinske energije od strane tog naručitelja neizbježna je posljedica obavljanja djelatnosti koja nije djelatnost iz stavka 1. ovog članka ili članaka od 9. do 11.; (b) jedini cilj isporuke javnoj mreži jest ekonomsko iskorištavanje takve proizvodnje i ne iznosi više od $20 \%$ prometa tog naručitelja uzimajući u obzir prosjek prethodne tri godine, uključujući tekuću godinu." Članak 8. Direktive 2014/25/ EU.

43 „Isporuka električne energije od strane naručitelja koji nije javni naručitelj fiksnim mrežama koje pružaju uslugu javnosti ne smatra se relevantnom djelatnošću u smislu stavka 1. ako su ispunjeni sljedeći uvjeti: (a) proizvodnja električne energije od strane tog naručitelja odvija se jer je potrošnja električne 
Značajne izmjene u primjeni Direktive na pružatelje usluga energije prisutne su u opsegu istraživanja i vađenja nafte, plina, ugljena ili drugih krutih goriva. Naime, iz opsega Direktive isključeno je istraživanje nafte i plina. Takva promjena uzrokovana je saznanjem da je za taj sektor uspostavljen takav konkurentski pritisak da disciplina u području nabave uvedena pravilima Unije o nabavi više nije potrebna. ${ }^{44}$ Tako su novom Direktivom obuhvaćene samo djelatnosti koje se odnose na iskorištavanje zemljopisnog područja u svrhu: vađenja nafte ili plina i istraživanja ili vađenja ugljena ili drugih krutih goriva. ${ }^{45}$ Kako je vađenje nafte i plina i dalje obuhvaćeno Direktivom, unesene su odredbe za lakše razlikovanje traženja (istraživanja) i vađenja. U skladu s tim, ,traženje” bi trebalo obuhvaćati aktivnosti poduzete kako bi se provjerilo jesu li nafta i plin prisutni u određenoj zoni, te, ako je tako, jesu li komercijalno iskoristivi, a „vađenje” bi se trebalo smatrati „proizvodnjom” nafte i plina. ${ }^{46}$

Iz područja primjene Direktive isključeni su javni naručitelji koji djeluju u području hlađenja. Javni naručitelji koji djeluju u području hlađenja podliježu pravilima Direktive 2014/24/EU jer javna i privatna poduzeća ne podliježu pravilima nabave, bez obzira na to djeluju li privatna poduzeća na temelju posebnih ili isključivih prava ${ }^{47}$ Ipak, ostavlja se mogućnost budućeg uključenja sektora hlađenja u primjenu ove Direktive nakon ispitivanja situacije u sektoru hlađenja kako bi se prikupilo dovoljno podataka, osobito onih vezanih uz konkurentsku situaciju, razinu prekogranične nabave i mišljenja zainteresiranih strana. ${ }^{48}$

Direktiva 2014/25/EU donosi i promjene u pragovima. Tako se direktiva primjenjuje na nabave čija je vrijednost bez poreza na dodanu vrijednost (PDV) jednaka ili veća od sljedećih pragova: 414.000 eura za ugovore o robi i uslugama te za projektne natječaje; 5.186.000 eura za ugovore o radovima; 1.000 .000 eura za ugovore o uslugama za društvene i druge posebne usluge navedene u Prilogu XVII. ${ }^{49}$ Kada nove pragove usporedimo s pragovima iz 2004., primjećujemo značajno snižavanje. Pragovi za ugovore o robi i uslugama sniženi su za 85.000 eura, dok su pragovi za ugovore o radovima sniženi za 1.056 .000 eura. Takvo snižavanje pragova značajno proširuje polje primjene nove Direktive. Novi pragovi posljedica su prilagodbe javnonabavnog regulatornog okviraSporazumu Svjetske trgovinske organizacije o javnoj nabavi (General procurement agreement-GPA) EU, a kako se GPA primjenjuje na ugovore iznad određenih pragova, određenih u GPA-u te

energije nužna kako bi se obavljala djelatnost osim djelatnosti iz stavka 1. ovog članka ili iz članaka 8., 10. i 11.;

(b) isporuka javnoj mreži ovisi samo o vlastitoj potrošnji naručitelja i ne iznosi više od $30 \%$ ukupne proizvodnje energije naručitelja uzimajući u obzir prosjek prethodne tri godine, uključujući tekuću godinu." Clanak 9. Direktive 2014/25/EU.

44 Paragraf 25. Direktive 2014/25/EU.

45 Članak 14. Direktive 2014/25/EU.

46 Paragraf 25. Direktive 2014/25/EU.

47 Paragraf 21. Direktive 2014/25/EU.

48 Paragraf 22. Direktive 2014/25/EU.

49 Članak 15. Direktive 2014/25/EU. 
izraženih u obliku posebnih prava vučenja (special drawing rights-SDR), pragovi utvrđeni ovom Direktivom trebali bi biti usklađeni kako bi se osiguralo da budu u skladu s istovjetnim pragovima GPA-a izraženima u eurima. ${ }^{50}$

\subsection{Isključenje djelatnosti izloženih tržišnom natjecanju}

Direktiva omogućava određenim komunalnim djelatnostima koje su u potpunosti izložene tržišnom natjecanju isključenje od primjene ove Direktive. Tako ugovori nisu predmet ove Direktive ako država članica ili naručitelji, nakon podnošenja zahtjeva, mogu dokazati da je djelatnost koja se obavlja u toj državi članici izravno izložena natjecanju na tržištima kojima pristup nije ograničen, a nisu predmet Direktive ni projektni natječaji koji se provode za obavljanje takve djelatnosti u tom geografskom području. ${ }^{51}$ Postupak utvrđivanja vodi Komisija, na temelju zahtjeva države članice ili naručitelja (ukoliko to zakonodavstvo države članice dopušta). ${ }^{52}$ Navedena mogućnost postojala je i u prethodnom regulatornom okviru, ali nova Direktiva mijenja rokove u kojima Komisija mora odlučiti o takvom zahtjevu države članice ili naručitelja. Tako sada Komisija mora odlučiti u roku od 90 radnih dana u slučajevima kada se slobodan pristup određenom tržištu može pretpostaviti, te u roku od 130 radnih dana u svim ostalim slučajevima. ${ }^{53}$ Navedeni rokovi produljuju se za 15 radnih dana ako zahtjev nije popraćen obrazloženim i utemeljenim stajalištem što ga je donijelo neovisno državno tijelo nadležno za dotičnu djelatnost, koje temeljito analizira uvjete za moguću primjenjivost izuzetka. ${ }^{54}$ Kako su rokovi u Direktivi 2004/17/EC bili tri mjeseca, ${ }^{55}$ nova Direktiva donosi značajno produljenje rokova i omogućava Komisiji lakše ocjenjivanje opravdanosti izuzetka za određenog naručitelja.

\subsection{Izmjene postojećih i nove vrste postupaka}

Nova Direktiva donosi značajne izmjene jednom postojećem javnonabavnom postupku - natjecateljskom dijalogu, i uvodi novi postupak - partnerstvo za inovacije. Natjecateljski dijalog je u prošlom javnonabavnom regulatornom okviru bio rezerviran za opće javnonabavne postupke, dok se u ovom regulatornom okviru uvodi i za pružatelje komunalnih usluga.

Potreba za ponovnim uvrštavanjem natjecateljskog dijaloga u Direktivu objašnjava se činjenicom da se pokazao korisnim u slučajevima u kojima javni naručitelji ne mogu utvrditi načine zadovoljavanja svojih potreba ili nisu u

\footnotetext{
50 Paragraf 28. Direktive 2014/25/EU.

51 Članak 34. stavak 1. Direktive 2014/25/EU.

52 Članak 35. stavak 1. Direktive 2014/25/EU.

53 Prilog IV Direktive 2014/25/EU.

54 Prilog IV Direktive 2014/25/EU.

55 Članak 30. stavak 6. Direktive 2004/17/EC.
} 
mogućnosti procijeniti što se nudi na tržištu u pogledu tehničkih, financijskih ili pravnih rješenja. Takva situacija pogotovo može nastati u slučaju inovativnih projekata, pri provedbi velikih integriranih projekata na području prometne infrastrukture, velikih računalnih mreža ili projekata koji obuhvaćaju složeno ili strukturirano financiranje. ${ }^{56}$ Novom Direktivom natjecateljski se dijalog mijenja te se povećava fleksibilnost njegova korištenja.

Tako se sada daje mogućnost da se ponude na zahtjev naručitelja mogu razjasniti, precizirati i prilagoditi. Međutim, takvo razjašnjenje, preciziranje, prilagodba ili dodatna informacija ne mogu uključivati promjene osnovnih odredbi ponude ili nabave, uključujući potrebe i zahtjeve utvrđene u pozivu na nadmetanje ili u opisnoj dokumentaciji, ako bi varijacija tih odredbi, potreba i zahtjeva vjerojatno mogla dovesti do narušavanja tržišnog natjecanja ili bi mogla imati diskriminirajući učinak. ${ }^{57}$ Vrlo slična odredba postojala je i u Direktivi 2004/18/EC, ${ }^{58}$ ali ta odredba nije sadržavala mogućnost prilagodbe ponude na zahtjev naručitelja. Takva mogućnost iz Direktive 2014/25/EU sigurno će doprinijeti fleksibilnosti i većoj mogućnosti prilagodbe u završnim fazama natjecateljskog dijaloga ${ }^{59}$

Nova Direktiva donosi i mogućnost pregovaranja s odabranim ponuditeljem. Tako se navodi da, na zahtjev naručitelja, pregovori s ponuditeljem za kojega je utvrđeno da je podnio ponudu koja predstavlja najbolji omjer između cijene i kvalitete mogu se voditi za potvrdu financijskih obveza ili drugih uvjeta ugovora, okončavajući uvjete ugovora, pod uvjetom da ti pregovori nisu vodili materijalnim izmjenama osnovnih aspekata ponude ili javne nabave, uključujući potrebe i zahtjeve utvrđene u obavijesti o nadmetanju ili u opisnoj dokumentaciji i da ne narušavaju tržišno natjecanje niti uzrokuju diskriminaciju. ${ }^{60}$ Mogućnost pregovaranja nije postojala u Direktivi 2004/18/EC, te se može očekivati kako će navedena odredba dodatno doprinijeti fleksibilnosti postupanja kod korištenja natjecateljskog dijaloga.

Partnerstvo za inovacije potpuno je novi javnonabavni postupak stavljen na raspolaganje naručiteljima koji pružaju komunalne usluge. Namijenjen je situacijama kada potrebu za razvojem inovativnog proizvoda ili usluge ili inovativnih radova te za naknadnom kupnjom te robe, usluga ili radova nije moguće zadovoljiti rješenjima koja su već dostupna na tržištu. ${ }^{61}$ Tada bi naručitelji trebali imati pristup posebnom postupku nabave, a taj postupak je upravo partnerstvo za inovacije. Partnerstvo za inovacije strukturirano je u uzastopnim fazama, poštujući redoslijed koraka u

56 Paragraf 60. Direktive 2014/25/EU.

57 Članak 48. stavak 6. Direktive 2014/25/EU.

58 „Na zahtjev javnog naručitelja, od ponuditelja koji je predao ekonomski najpovoljniju ponudu, može biti zatraženo da pojasni aspekte ponude ili potvrdi obaveze sadržane u ponudi pod uvjetom da to nema učinak mijenjanja bitnih aspekata ponude ili poziva na nadmetanje i ne izlaže javnog naručitelja riziku narušavanja tržišnog natjecanja ili uzrokovanja diskriminacije." Članak 29. stavak 7. Direktive 2004/18/EC.

59 Tako i Kotsonis, T., „The 2014 Utilities Directive of the EU: Codification, Flexibilisation and Other Misdemeanours“, Public Procurement Law Review 4 2014., str. 171.

60 Članak 48. stavak 7. Direktive 2014/25/EU.

61 Paragraf 59. Direktive 2014/25/EU. 
procesu istraživanja i inovacija koji mogu uključiti proizvodnju robe, pružanje usluga ili dovršenje radova. Partnerstvo za inovacije utvrđuje privremene ciljeve koje partneri trebaju dosegnuti, kao i plaćanje naknade u odgovarajućim obrocima. $\mathrm{Na}$ osnovi tih ciljeva naručitelj može odlučiti nakon svake faze raskinuti partnerstvo za inovacije ili, u slučaju partnerstva za inovacije s nekoliko partnera, smanjiti broj partnera raskidanjem pojedinačnih ugovora, pod uvjetom da je naručitelj u dokumentaciji o nabavi naveo te mogućnosti, kao i uvjete za njihovo korištenje. ${ }^{62}$

\subsection{Okvirni sporazumi}

Okvirni su sporazumi novom Direktivom dodatno pojašnjeni i njihova je primjena dodatno liberalizirana, s obzirom na regulatorni okvir iz 2004., ali i na novu opću javnonabavnu Direktivu 2014/24/EU. Tako se okvirni sporazum definira kao sporazum između jednog ili više naručitelja i jednog ili više gospodarskih subjekata, a čija je svrha utvrđivanje uvjeta pod kojima se dodjeljuju ugovori tijekom određenog razdoblja, posebno u pogledu cijene i, po potrebi, predviđenih količina. ${ }^{63}$ Nije izmijenjen uvjet da se okvirni sporazumi moraju koristiti na način da ne sprečavaju i otežavaju tržišno natjecanje, ${ }^{64}$ ali se uvode rokovi trajanja okvirnih sporazuma. Tako trajanje okvirnog sporazuma više ne može biti dulje od 8 godina, osim u iznimnim valjano opravdanim slučajevima posebno vezanima uz predmet okvirnog sporazuma. ${ }^{65}$ Navedenom je odredbom duljina trajanja okvirnih sporazuma određena znatno šire nego u općoj Direktivi 2014/24/EU, gdje je bio propisan rok od 4 godine. ${ }^{66}$

\subsection{Razdioba ugovora u grupe}

Razdioba ugovora u grupe postojala je i u Direktivi 2004/17/EC. Ipak, nova Direktiva donosi mogućnost ograničenja broja grupa koje se mogu dodijeliti jednom ponuditelju. Tako naručitelji mogu, čak i ako se ponude mogu podnijeti za nekoliko grupa ili za sve, ograničiti broj grupa koje se mogu dodijeliti jednom ponuditelju, pod uvjetom da je maksimalan broj grupa po ponuditelju naveden u obavijesti o nadmetanju ili u pozivu na potvrdu interesa, u pozivu na podnošenje ponuda ili u pozivu na pregovore ${ }^{67}$ Ove su odredbe uvedene kako bi se potaklo sudjelovanje malih i srednjih poduzetnika u postupcima javne nabave i kako bi se smanjila mogućnost pretjerane ovisnosti naručitelja o jednom ponuditelju. ${ }^{68}$

62 Članak 49. stavak 2. Direktive 2014/25/EU.

63 Članak 51. stavak 1. Direktive 2014/25/EU.

64 Članak 51. stavak 2. Direktive 2014/25/EU.

65 Članak 51. stavak 1. Direktive 2014/25/EU.

66 Članak 33. stavak 1. Direktive 2014/24/EU.

67 Članak 65. stavak 2. Direktive 2014/25/EU.

68 Tako i Kotsonis, T., op. cit. (bilj. 59.), str. 174. 


\subsection{Raskid ugovora}

Odredbe o raskidu ugovora nova su značajna izmjena u javnonabavnom regulatornom okviru iz 2014. Iako su te odredbe identične i u općoj Direktivi 2014/24/EU i u predmetnoj Direktivi 2014/25/EU, smatramo ih bitnim spomenuti jer energetskim, ali i ostalim komunalnim naručiteljima omogućavaju značajan utjecan na već sklopljene ugovore. Tako je člankom 90. Direktive 2014/25/EU propisano kako su države članice dužne sigurati da naručitelji mogu raskinuti ugovor o radovima, robi ili uslugama tijekom njegova trajanja ako je ugovor značajno izmijenjen, što bi zahtijevalo novi postupak nabave, ako je u vrijeme dodjele ugovora ugovaratelj počinio jedan od obveznih razloga za isključenje iz članka 57. stavka 1. Direktive 2014/24/EU te je stoga trebao biti isključen iz postupka nabave, i ako se ugovor nije trebao dodijeliti ugovaratelju u svjetlu ozbiljne povrede obveza prema Ugovorima i ovoj Direktivi, koju je proglasio Sud Europske unije u postupku prema članku 258. UFEU-a. ${ }^{69}$

\section{JAVNA NABAVA ZA ENERGETSKE NARUČITELJE U REPUBLICI HRVATSKOJ}

\section{1. Zakonodavni okvir za javnu nabavu i energetsku učinkovitost u Republici Hrvatskoj}

Zakonodavni okvir za javnu nabavu i energetsku učinkovitost u Republici Hrvatskoj čine: Zakon o javnoj nabavi, ${ }^{70}$ Zakon o energetskoj učinkovitosti, ${ }^{71}$ Zakon o promicanju čistih i energetski učinkovitih vozila u cestovnom prijevozu, ${ }^{72}$ Strategija održivog razvitka Republike Hrvatske, ${ }^{73}$ Strategija energetskog razvoja Republike Hrvatske ${ }^{74}$ i Treći nacionalni akcijski plan za energetsku učinkovitost.

Zakon o javnoj nabavi uređuje postupke sklapanja ugovora o javnoj nabavi i okvirnih sporazuma radi nabave roba, radova i usluga, pravnu zaštitu u vezi s tim postupcima i nadležnost središnjeg tijela državne uprave za sustav javne nabave. Zakonom o javnoj nabavi propisane su procedure koje naručitelji moraju poštovati pri provedbi postupaka za nabavu roba, radova i usluga.

Zakon o energetskoj učinkovitosti uređuje: područje učinkovitog korištenja energije, donošenje planova za poboljšanje energetske učinkovitosti na lokalnoj,

\footnotetext{
69 Ista je formulacija i u članku 73. Direktive 2014/24/EU.

70 Narodne novine, broj 90/2011, 83/2013, 143/2013 i 13/2014.

1 Narodne novine, broj 127/2014.

72 Narodne novine, broj 127/2013.

73 Narodne novine, broj 30/2009.

74 Narodne novine, broj 130/2009.
} 
područnoj (regionalnoj) i nacionalnoj razini, mjere energetske učinkovitosti te njihovo provođenje, obveze energetske učinkovitosti, obveze regulatornog tijela za energetiku, operatora prijenosnog sustava, operatora distribucijskog sustava i operatora tržišta energije u svezi s prijenosom, odnosno transportom i distribucijom energije, obveze distributera energije, opskrbljivača energije i/ili vode, a posebice djelatnost energetske usluge, utvrđivanje ušteda energije te prava potrošača u primjeni mjera energetske učinkovitosti.

Kod provođenja postupka javne nabave za proizvode povezane s energijom, javni naručitelj je dužan koristiti kriterije za odabir ponude i tehničke specifikacije vezane uz povećanje energetske učinkovitosti u mjeri u kojoj je to u skladu s troškovnom učinkovitošću, gospodarskom izvedivošću, širom održivošću, tehničkom prikladnošću i dovoljnom razinom tržišnog natjecanja. Navedeni kriteriji i tehničke specifikacije utvrđuju se pravilnikom.

Zakon o promicanju čistih i energetski učinkovitih vozila u cestovnom prijevozu propisuje mjere za promicanje uporabe čistih i energetski učinkovitih vozila u cestovnom prijevozu, radi poticanja tržišta čistih i energetski učinkovitih vozila i zaštite okoliša, klime i energetike. Naručitelji su u postupku javne nabave dužni pri kupnji vozila kojima se obavlja cestovni prijevoz uzimati u obzir energetske učinke i utjecaj na okoliš tijekom razdoblja eksploatacije vozila, uključujući potrošnju energije te emisije ugljikovog dioksida $\left(\mathrm{CO}_{2}\right)$ i određenih onečišćivača.

Strategija održivog razvitka sadrži temeljna načela i mjerila za određivanje ciljeva i prioriteta u promišljanju dugoročne preobrazbe prema održivom razvoju Republike Hrvatske. Imajući to u vidu, Strategija postavlja osnovne ciljeve i mjere održivog razvitka gospodarstva, socijalnog razvitka i zaštite okoliša te identificira ključne izazove u njihovu ostvarivanju. U Strategiji su navedene institucije uključene u njezinu provedbu, način provedbe, odgovornost za provedbu te način praćenja provedbe. Strategija energetskog razvoja u okviru dokumenta Strateški okvir za razvoj od 2006. do 2013. godine, ima za svrhu: definiranje razvoja energetskog sektora Republike Hrvatske za razdoblje do 2020. godine i izgradnju održivog energetskog sustava Republike Hrvatske u neizvjesnim uvjetima globalnog tržišta energije i uz oskudne domaće energetske resurse. Naime, jedan od ciljeva Strategije Europa 2020., usvojene 2010. godine na razini Europske unije, jest povećanje udjela obnovljivih izvora energije u konačnoj potrošnji energije na $20 \%$. S tim u vezi, u Republici Hrvatskoj usvojena je strategija održivog razvoja Republike Hrvatske, ${ }^{75}$ kojom su utvrđene smjernice dugoročnog djelovanja te temeljna načela i mjerila za određivanje ciljeva i prioriteta. Obnovljivi su izvori energije obnovljivi nefosilni izvori energije odnosno energija vjetra, sunčeva energija, aerotermalna, geotermalna i hidrotermalna energija, energija mora, energija vodotoka, energija iz biomase, plina iz deponija otpada, plina iz postrojenja za obradu otpadnih voda i bioplina. ${ }^{76}$ Sud iz Luksemburga već je prihvatio da naručitelj može uzeti u obzir „ekološke kriterije“ za dodjelu javnih ugovora (Sud pravde Europskih zajednica,

75 Narodno novine, broj 30/09.

76 Narodne novine, broj 22/13, Zakon o tržištu električne energije, članak 3. 
17. rujna 2002., Concordia Bus, Finland Oy AB protiv Helsnigin Kaupunkt, HKL - Bussiliikenne). To posebice vrijedi za opskrbu električne energije iz obnovljivih izvora energije (Sud pravde Europskih zajednica, 4. prosinca 2003., EVN AG protiv Austrije). Prije toga, Sud je već omogućio lokalnim zajednicama uključivanje u proizvodnju energije iz obnovljivih izvora, delegirajući pravila o tržišnom natjecanju (Sud pravde Europskih zajednica, 18. studenoga 1999., Teckal Srl protiv Comune di Viano).

Europska unija nastoji poboljšati europsko energetsko tržište na način da bude bolje koordinirano ${ }^{77}$ jer u ujedinjenoj Europi nije više moguće djelovati izdvojeno. Proizvodnja energije iz obnovljivih izvora velikih razmjera zahtijeva međusobno povezano europsko energetsko tržište, ako se žele postići ciljevi utvrđeni programom „Energija i klima“" usvojenim 2009. Njime se u razdoblju do 2020. predviđa: smanjenje emisije ugljičnog dioksida od barem $20 \%$ u odnosu na 1990., poboljšanje energetske učinkovitosti od $20 \%$, udio proizvodnje energije iz obnovljivih izvora od barem $20 \%$ u odnosu na ukupnu potrošnju energije.

Ovaj razvoj nazvan je „energetska tranzicija“ i mora dovesti zemlje članice EU do smanjenja emisija stakleničkih plinova za najmanje $80 \%$ do 2050 . No, to pretpostavlja promjenu paradigme u temeljima naših gospodarstava i društva. ${ }^{78}$ Prema trenutnoj dinamici, Europa bi do 2050. smanjila emisiju ugljičnog dioksida tek za $40 \%$. Upravo bi u sljedećih 20 ili 30 godina trebalo korjenito izmijeniti energetske sustave, načine prijevoza, industrijsku i poljoprivrednu proizvodnju, pa čak i organizaciju života u gradu. ${ }^{79}$

Da bi se zelena energija mogla koristiti, trebat će napraviti promjenu u elektroenergetskoj mreži. Godine 2012., 34 države europskog kontinenta sa 525 milijuna stanovnika povezane su sa $305.000 \mathrm{~km}$ dalekovoda za prijenos električne energije. Međusobne veze služe tome da apsorbiraju značajne i brze varijacije u isporuci električne energije, da učine tržište protočnijim, da omoguće različitim proizvodnim sustavima da djeluju komplementarno, da spoje masovno širenje energije iz obnovljivih izvora. Uloga energetskih mreža ,u odnosu na pitanje okoliša, afirmira se sve više i više u srcu naše postindustrijske civilizacije“ ".0 ${ }^{80}$ Sto je europska mreža veća, to je veći i njezin kapacitet za apsorpciju varijacija u proizvodnji. Ta

77 Radi se o rješavanju problema koji su nastali u nekim državama 2006. i 2009., kao i incident koji se dogodio na mreži u sjevernoj Njemačkoj, ili kriza u opskrbi plinom zbog odluke kojom je Moskva obustavila isporuku plina Ukrajini.

78 To uključuje preustroj stanova, pretvarajući svako domaćinstvo u mini-elektranu za proizvodnju električne energije koja na licu mjesta može iskorištavati energiju iz obnovljivih izvora. Potrebno je također riješiti problem pohrane zelene energije jer je energija iz obnovljivih izvora nestalna (ovisno o količini vjetra i sunca). Konačno, u prijevozu, raširena uporaba električnih vozila zahtijeva postavljanje stanica za punjenje posvuda.

79 J. Rifkin, ,Vers une troisième révolution industrielle“, in: Politique Internationale, str. 373 i s.

80 C. Bouneau, „Les grands réseaux techniques, pères fondateurs de l'Europe“, in: Politique Internationale, str. 399 i s. Slučaj Španjolske poučan je u tom smislu. U stvari, ova zemlja ima infrastrukturu za proizvodnju zelene energije, posebice za proizvodnju energije iz vjetra, ali kako nema dostatnu međusobnu povezanost, vjetroturbine moraju zaustaviti svoju proizvodnju. O tom aspektu, D. Maillard, „Les réseaux au cœur du système électrique européen“, in: Politique Internationale (précité), str. 341 is. 
činjenica isto tako omogućuje svakoj zemlji da koristi svoje lokalne resurse. K tome, raznolikost mogućnosti potiče komplementarnost, koja je poželjnija nego ujednačenost izbora. Jer električna energija nastala iz vjetra i sunca po prirodi je nestalna.

S tim u vezi, na temelju Nacionalnog akcijskog plana za zelenu javnu nabavu za razdoblje od 2015. - 2017. s perspektivom do 2020. godine, donesenog 26. kolovoza 2015. godine, kao osnovno mjerilo zelene javne nabave za električnu energiju, predviđena je nabava barem $50 \%$ električne energije iz obnovljivih izvora i/ili nabava električne energije iz visokoučinkovite kogeneracije (s tim da ponuđač treba navesti udio električne energije iz obnovljivih izvora kojom misli opskrbiti naručitelja). Nastavno na navedeno, a i radi stimuliranja proizvodnje energije iz obnovljivih izvora kako bi ona postala konkurentnija energiji dobivenoj iz konvencionalnih izvora te radi poticanja izgradnje novih izvora obnovljive energije i postizanja održivog razvoja, Naručitelj je odredio da električna energija koja će se isporučivati korisnicima temeljem predmetnog okvirnog sporazuma mora sadržavati minimalno $50 \%$ električne energije iz obnovljivih izvora.

Obveznici primjene Zakona o javnoj nabavi omogućit će postizanje veće energetske učinkovitosti provedbom sustava javne nabave za projekte energetske učinkovitosti na transparentan način. To je najjednostavnije ostvariti izradom primjera standardnih ugovora za pojedine vrste nabave, izradom detaljnih uputa za procjenu ušteda kod različitih projekata energetske učinkovitosti, razradom sustava mjerenja te redovnim obavljanjem nadzora nad ostvarenim uštedama.

Treći nacionalni akcijski plan za energetsku učinkovitost predstavlja sveobuhvatni provedbeni dokument politike energetske učinkovitosti za trogodišnje razdoblje (2014. - 2016.), a ujedno sadrži i izvješće s detaljnim prikazom aktivnosti provedenih u prethodnom s ocjenom ostvarenih ušteda energije u odnosu na ciljeve postavljene u Drugom nacionalnom akcijskom planu za energetsku učinkovitost Republike Hrvatske do kraja 2013. godine. Prema Trećem nacionalnom akcijskom planu potrebno je intenzivirati aktivnosti kojima će se osigurati pravna i tehnička znanja i vještine javnih naručitelja za uključivanje i vrednovanje zahtjeva za energetskom učinkovitosti u postupcima javne nabave primjenom kriterija ekonomski najpovoljnije ponude. U Akcijskom je planu navedeno da se planira izrada nacionalnog Akcijskog plana za zelenu javnu nabavu koji će identificirati ključne dionike i mjere koje treba poduzeti na nacionalnoj i lokalnoj razini, kako bi se kriteriji Zakona o javnoj nabavi što bolje integrirali u postupak javne nabave. Preporučat će se korištenje kriterija zelene javne nabave koje je izradila Europska komisija, a koji obuhvaćaju i pokazatelj energetske učinkovitosti. 


\subsection{Sektorski naručitelji}

Na temelju članka 5. stavka 2. i članka 6. stavka 3. Zakona o javnoj nabavi donesen je Pravilnik o popisu obveznika primjene Zakona o javnoj nabavi ${ }^{81}$ koji propisuje popis javnih naručitelja i sektorskih naručitelja.

Sektorski su naručitelji oni naručitelji koji sukladno posebnim propisima obavljaju djelatnosti: 1. izgradnje (pružanja) nepokretnih mreža ili upravljanja nepokretnim mrežama za pružanje usluge javnosti u vezi s proizvodnjom, prijenosom ili distribucijom plina ili toplinske energije, te isporuke plina ili toplinske energije nepokretnim mrežama, kao što su subjekti koji navedene djelatnosti obavljaju na temelju Dozvole za obavljanje energetske djelatnosti sukladno Zakonu o energiji, ${ }^{82}$ primjerice HEP Plin d.o.o., Gradska plinara Zagreb d.o.o., Energo d.o.o., Plinara d.o.o., Plinacro d.o.o., HEP Toplinarstvo d.o.o.; 2. izgradnje (pružanja) nepokretnih mreža ili upravljanja nepokretnim mrežama za pružanje usluge javnosti u vezi s proizvodnjom, prijenosom ili distribucijom električne energije, te isporuke električne energije nepokretnim mrežama, kao što su subjekti koji navedene djelatnosti obavljaju na temelju Dozvole za obavljanje energetske djelatnosti sukladno Zakonu o energiji ${ }^{83}$ primjerice HEP - OPS d.o.o., HEP - ODS d.o.o.; 3. koje se odnose na iskorištavanje zemljopisnog područja $u$ svrhu istraživanja ili vađenja nafte $i$ plina, kao što su subjekti koji obavljaju navedene djelatnosti na temelju odobrenja ili koncesije sukladno Zakonu o rudarstvu; ${ }^{84} 4$. koje se odnose na iskorištavanje zemljopisnog područja u svrhu istraživanja ili vađenja ugljena ili drugih krutih goriva, kao što su subjekti koji obavljaju navedene djelatnosti na temelju odobrenja ili koncesije sukladno Zakonu o rudarstvu: ${ }^{85} 5$. izgradnje (pružanja) nepokretnih mreža ili upravljanja nepokretnim mrežama za pružanje usluge javnosti u vezi s proizvodnjom, prijenosom ili distribucijom pitke vode, te isporuka pitke vode nepokretnim mrežama, kao što su pravne osobe koje osnivaju jedinice lokalne samouprave u svojstvu javnog isporučitelja vodnih usluga javne vodoopskrbe ili javne odvodnje sukladno Zakonu o vodama, ${ }^{86}$ primjerice Vodovod i kanalizacija d.o.o. Karlovac, Vodovod d.o.o. Slavonski Brod; 6. pružanja poštanskih usluga i drugih usluga koje ne uključuju poštanske usluge pod uvjetima iz članka 112. stavka 4. Zakona; primjerice HP - Hrvatska pošta d.d.; 7. stavljanja na raspolaganje mreža ili upravljanje mrežama koje pružaju uslugu javnosti u području prijevoza željeznicom; primjerice HŽ Infrastruktura d.o.o.; 8. stavljanja na raspolaganje mreža ili upravljanje mrežama koje pružaju uslugu javnosti u području prijevoza gradskom željeznicom, automatiziranim sustavima, tramvajem, autobusom, trolejbusom ili žičarom, kao što su subjekti koji obavljaju navedene djelatnosti kao javnu službu

\footnotetext{
81 Narodne novine, broj 19/12.

82 Narodne novine, broj 68/01, 177/04, 76/07, 152/08, 127/10.

83 Narodne novine, broj 68/01, 177/04, 76/07, 152/08, 127/10.

84 Narodne novine, broj 75/09 i 49/11.

85 Narodne novine, broj 75/09 i 49/11.

86 Narodne novine, broj 153/09 i 130/11.
} 
sukladno Zakonu o komunalnom gospodarstvu, ${ }^{87}$ primjerice Zagrebački holding d.o.o. podružnica Zagrebački električni tramvaj - ZET, Liburnija d.o.o., KD Autotrolej d.o.o.; 9. koje se odnose na iskorištavanje zemljopisnog područja u svrhu pružanja usluga morskih ili riječnih luka, ili druge terminalne opreme prijevoznicima u pomorskom ili riječnom prijevozu, kao što su subjekti koji obavljaju navedene djelatnosti na temelju koncesije sukladno Zakonu o pomorskom dobru i morskim lukama ${ }^{88}$ primjerice Luka Pula, Luka Rijeka, Luka Zadar, Luka Šibenik, Luka Split d.d., Luka Ploče, Luka Dubrovnik, Luka Vukovar; 10. koje se odnose na iskorištavanje zemljopisnog područja u svrhu pružanja usluga zračnih luka, ili druge terminalne opreme prijevoznicima u zračnom prijevozu, kao što su subjekti koji obavljaju navedene djelatnosti na temelju koncesije sukladno Zakonu o zračnim lukama, ${ }^{89}$ primjerice Zračna luka Zagreb, Zračna luka Split, Zračna luka Rijeka, Zračna luka Osijek, Zračna luka Pula, Zračna luka Zadar, Zračna luka Brač.

\subsection{Zakon o javnoj nabavi i sektorski naručitelji}

Zakon o javnoj nabavi sadrži posebne odredbe koje primjenjuju sektorski naručitelji kada nabavljaju robu, radove ili usluge za potrebe djelatnosti na području: plina, toplinske energije i električne energije; vodoopskrbe; istraživanja ili vađenja nafte, plina, ugljena ili ostalih krutih goriva; prijevoznih usluga; djelatnosti zračnih, morskih i riječnih luka i poštanskih usluga.

Predmetni zakon isto tako prebrojava djelatnosti na području plina i toplinske energije: izgradnja (pružanje) nepokretnih mreža ili upravljanje nepokretnim mrežama za pružanje usluge javnosti u vezi s proizvodnjom, prijenosom ili distribucijom plina i toplinske energije; isporuka plina ili toplinske energije nepokretnim mrežama. Također navodi i djelatnosti na području električne energije: izgradnja (pružanje) nepokretnih mreža ili upravljanje nepokretnim mrežama za pružanje usluge javnosti u vezi s proizvodnjom, prijenosom ili distribucijom električne energije; isporuka električne energije nepokretnim mrežama. Ako sektorski naručitelj koji nije javni naručitelj isporučuje električnu energiju mrežama koje pružaju uslugu javnosti, takva djelatnost ne smatra se djelatnošću izgradnje (pružanja) nepokretnih mreža ili upravljanja nepokretnim mrežama za pružanje usluge javnosti u vezi s proizvodnjom, prijenosom ili distribucijom električne energije te isporuke električne energije nepokretnim mrežama ako isporuka javnoj mreži ovisi samo o vlastitoj potrošnji naručitelja i ne iznosti više od $30 \%$ ukupne proizvodnje energije naručitelja u odnosu na prosjek prethodne tri godine, uključujući i tekuću godinu.

87 Narodne novine, broj 36/95, 70/97, 128/99, 57/00, 129/00, 59/01, 26/03, 82/04, 110/04, 178/04, 38/09, 79/09, 153/09, 49/11, 84/11, 90/11.

88 Narodne novine, broj 158/03, 100/04, 141/06 i 38/09.

89 Narodne novine, broj 19/98 i 14/11. 


\section{ZAKLJUČAK}

Rok od dvije godine za implementaciju u nacionalno zakonodavstvo Direktivi 2014/24/EU koja se odnosi na javne naručitelje i Direktivi 2014/25/EU koja se odnosi na sektorske naručitelje u području javne nabave protekao je 18. travnja 2016., a da nije donesen novi Zakon o javnoj nabavi. Iako je postojeći Zakon o javnoj nabavi u većoj mjeri usklađen s njihovim odredbama, nove direktive ipak unose određene promjene i novine u sustav javne nabave. S obzirom na to da članak 145. Ustava Republike Hrvatske propisuje da je ostvarivanje prava koja proizlaze iz pravne stečevine Europske unije izjednačeno s ostvarivanjem prava koja su zajamčena hrvatskim pravnim poretkom, te na sadržaj Ugovora o funkcioniranju Europske unije i na sam učinak direktiva, Ministarstvo gospodarstva je mišljenja ${ }^{90}$ da bi naručitelji, u smislu Zakona o javnoj nabavi u postupcima javne nabave velike vrijednosti, započetim od 18. travnja 2016., uz odredbe Zakona o javnoj nabavi, morali uzeti u obzir i odredbe Direktive 2014/24/EU i Direktive 2014/25/EU koje su bezuvjetne i dovoljno određene. ${ }^{91}$ Predmetne Direktive primjenjuju se na vrijednosti nabave jednake ili veće od pragova EU. Naime, izravna primjena odredbi direktiva odnosi se isključivo na nabave velike vrijednosti (zbog novonastale situacije i činjenice da Republika Hrvatska na vrijeme nije transponirala odredbe direktiva u nacionalno zakonodavstvo), te za nabave male vrijednosti naručitelji nastavljaju primjenjivati važeći Zakon o javnoj nabavi kao i do sada (do stupanja na snagu novog Zakona o javnoj nabavi). Europska komisija usvojila je 5. siječnja 2016. Provedbenu uredbu (EU) 2016/7 o utvrđivanju standardnog obrasca za europsku jedinstvenu dokumentaciju o nabavi. Uredbom je uvedena Europska jedinstvena dokumentacija o nabavi. Europska jedinstvena dokumentacija je osobna izjava gospodarskih subjekata koja predstavlja preliminarni dokaz kojim se zamjenjuju potvrde izdane od tijela javne vlasti ili od trećih osoba. Europska jedinstvena dokumentacija jest službena izjava gospodarskog subjekta da: nije u jednoj od situacija u kojoj se gospodarski subjekti isključuju ili se mogu isključiti, ispunjava odgovarajuće kriterije za odabir gospodarskog subjekta i ispunjava objektivna pravila i kriterije određene u svrhu ograničavanja broja kvalificiranih natjecatelja koji će se pozvati na sudjelovanje. Provedbena uredba u cijelosti je obvezujuća i izravno se primjenjuje od 18. travnja 2016. u svim državama članicama, pa samim time i u Republici Hrvatskoj. Objavljena je u Službenom listu Europske unije L 3/2016 od 6. siječnja 2016. ${ }^{92}$ Vlada Republike Hrvatske, na sjednici održanoj 24. studenoga 2016., utvrdila je Konačni prijedlog Zakona o javnoj nabavi te ga uputila Hrvatskom saboru na raspravu i usvajanje. Predloženim Zakonom u hrvatski pravni sustav implementiraju se Direktiva 2014/24/EU i Direktiva 2014/25/EU Europskog parlamenta i Vijeća od 26. veljače 2014.

\footnotetext{
90 Detaljno mišljenje Ministarstva gospodarstva pogledajte na http://javnanabava.hr/default. aspx?id=5107

$91 \mathrm{http}: / /$ www.javnanabava.hr/default.aspx?id=5107

92 http://eur-lex.europa.eu/legal-content/HR/TXT/HTML/?uri=CELEX:32016R0007\&from=HR
} 


\section{SPECIFITIES OF PUBLIC PROCUREMENT IN ENERGY SECTOR CONSIGNEES}

In this paper, differential regulation and procedural application of public procurement to the procurement procedures of sector consignees in all kinds of activities concerning energy are analysed. Analysis consists of two parts, European and Croatian. In the European part public procurement by consignees carrying out activities concerning energy is inseparable from the wider concept of ,utilities“. Therefore, the development of the application of public procurement rules to procurement consignees providing services concerning energy in the context of historical and contemporary legal understandings of utilities is analysed. Also, changes to the public procurement rules applicable to consignees of energy are analysed. In the second part, the legal framework for consignees of energy in the Republic of Croatia is analysed.

Key words: public procurement, activities concerning energy, European Union, Republic of Croatia 